\title{
Kurumsal Yetkinlik ile Satın Alma Niyeti Arasındaki İlişkide Müşteri Kurum Özdeşlemesi ve Algılanan Olumsuz Duyurumun Etkisine Yönelik Bir Araştırma
}

\section{An Investigation on the Effects of Customer-Company Identification and Perceived Negative Publicity on the Relationship between Corporate Ability and Purchase Intention}

\author{
Dr. Öğr. Üyesi Aslı TOLUNAY KUŞÇU ${ }^{\text {iD }}$, Doç. Dr. Merve KOÇOĞLU SAZKAYA (D2, \\ Dr. Öğr. Üyesi Burçak VATANSEVER DURMAZ ${ }^{\text {Di } 3}$
}

$\ddot{\mathbf{O z}}$

Bu çalışmada, bir işletmenin çok çeşitli özelliklerini özetleyen soyut boyutlar toplamı olan kurumsal yetkinlik ile müşterilerin satın alma niyeti arasındaki ilişside müşteri kurum özdeşleşmesinin ve algılanan olumsuz duyurumun rolleri üzerinde durulmuştur. Bahsi geçen kavramlar arasındaki iliş̧kiyi tespit etmek amacıyla araştırma, bir vakıf üniversitesinde yüksek lisans eğitimi alan ve çalışma hayatında olan kişiler üzerinde gerçekleştirilmiş ve veri toplamada Türk tüketicileri tarafından bu kavramlar ile ilişkilendirilebileceği düşünülen ve kısa bir süre önce olumsuz bir duyurum yapılmış olan bilinirliği yüksek bir otomotiv işletmesi kullanılmıştır. Elde edilen verinin incelenmesinde yapısal eşitlik modeli kullanılmıştır. Araştırma sonuçları, kurumsal yetkinlik ile satın alma niyeti arasındaki ilişkide müşteri kurum özdeşleşmesinin tam arac1lık etkisi olduğunu göstermekte ve müşteri kurum özdeşleşmenin önemine dikkat çekmektedir. Aynı zamanda, bu çalışmada, algılanan olumsuz duyurumun satın alma niyetini olumsuz yönde etkilediği ve buna bağlı olarak da kurumsal yetkinlik ve satın alma niyeti arasındaki ilişkiyi azalttığı, dolayısıyla olumsuz duyurumun kurumsal yetkinlik ile satın alma niyeti arasındaki ilişkide düzenleyici etkisi olduğu sonucuna varılmıştır. Genel olarak çalışmanın sonuçları müşteriler tarafından yetkin bulunan bir kurumda dahi gerek müşterilerde oluşan olumlu algının sonucunda gerçekleşen müşteri kurum özdeşleşmesinin olumlu etkisini, gerekse olumsuz duyurumların algısının satın alma niyetine olan olumsuz etkisini göstermektedir. Çalışmanın sonunda sonuçlar doğrultusunda kurumlara müşteri kurum özdeşleşmesini ve olumsuz duyurumları yönetmeleri doğrultusunda öneriler verilmiş̧ir.

Anahtar Kelimeler: Kurumsal yetkinlik, müşteri kurum özdeşleşmesi, algılanan olumsuz duyurum, satın alma niyeti

Makale Türü: Araştırma

\begin{abstract}
This study investigates the roles of consumer-company identification and perceived negative publicity within the relationship between perceived corporate ability which is the sum of the various intangible aspects that summarize a company's characteristics and consumers' purchase intention. Graduate students of a private university, who are also actively working at an organization, were approached and a well-
\end{abstract}

\footnotetext{
${ }^{1}$ Yeditepe Üniversitesi, İktisadi ve İdari Bilimler Fakültesi, asli.kuscu@yahoo.com.

${ }^{2}$ Marmara Üniversitesi, İşletme Fakültesi, merve.kocoglu@marmara.edu.tr.

${ }^{3}$ Bahçeşehir Üniversitesi, Sosyal Bilimler Enstitüsü, burcak.vatansever@gss.bau.edu.tr.
}

Atıf için (to cite): Tolunay Kuşçu, A., Koçoğlu Sazkaya, M. ve Vatansever Durmaz, B. (2019). Kurumsal yetkinlik ile satın alma niyeti arasındaki ilişkide müşteri kurum özdeşlemesi ve algılanan olumsuz duyurumun etkisine yönelik bir araştırma. Afyon Kocatepe Üniversitesi Sosyal Bilimler Dergisi, 22(1), 163-179. 
known automobile company which has recently undergone a negative publicity incident and therefore can be associated with the concepts in the study was used to collect data. Structural equation modeling was used to analyze the proposed relationships. Results of the study indicate that consumer-company identification fully mediates the relationship between corporate ability and purchase intention and highlight the importance of identification. Moreover, the study demonstrates that perceived negative publicity has a negative influence on purchase intention and weakens the impact of corporate ability on purchase intention. In general, results of the study show that there is not only a positive influence of identification raised by positive associations but also a negative impact of negative publicity on consumers' purchase intention even in the case of a company with high corporate ability. The study concludes with some suggestions to companies on managing identification and negative publicity.

Keywords: Corporate ability, consumer-company identification, perceived negative publicity, purchase intention

Paper Type: Research

Giriş

İşletmeler müşteriler sayesinde var olurlar. Müşteriler tarafından beğenilmeyen, ürünleri satın alınmayan işletmelerin varlıklarını devam ettirmeleri mümkün değildir. İşletmelerin başarısı ve devamı açışından çalışmalar bu sebeple bu noktada müşteri davranışlarına yönelmiş ve müşterilerin satın alma niyetlerini ve bunları etkileyen unsurları irdelemeye başlamıștır. İşletmelerin müşterilerin zihnindeki yeri, bir başka deyişle işletmenin müşterilerdeki itibarı müşterilerin satın alma kararını etkilemekte (Labay ve Kinnear, 1981), müşteri sadakatini arttırmakta ve dolayısıyla işletmelerin başarısında önemli bir yer teşkil etmektedir (Herbig ve Milewicz, 1995). Bir başka ifadeyle, müşterilerin işletmelere yönelik müspet bir algı beslemeleri müşterilerin kararlarını olumlu yönde etkileyerek satın alma isteklerini ve sonuç olarak satın almalarını arttırabilmektedir. Bu doğrultuda yapılan çalışmalarda itibarın stratejik bir kaynak olarak finansal başarıdaki önemi vurgulanmıştır (Deephouse, 2002). İşletme imajı ya da itibarı müşterilerin çeşitli kaynakları kullanarak (deneyim, reklam, ağızdan ağıza pazarlama) derledikleri bilgileri işletmenin tutarlılığı ve güvenilirliği gibi özellikleri açısından değerlendirmeleri sonucunda uzun dönemde oluşturdukları (Bennett ve Rentschler, 2003) işletmeye yönelik algılarının tümüdür (Weiwei, 2007). Bu sebeple itibarı olıuşturan ve etkileyen birçok faktör siralanabilmektedir. Brown ve Dacin (1997) itibarı kurumsal yetkinlik ve kurumsal sosyal sorumluk boyutlarından oluşan bir kavram olarak tanımlamaktadır. Bu çerçevede bir işletmenin itibarını ve de sonrasında müşterinin satın alma kararını o işletmenin etik kurallara uygun davranması, ürünlerinin kalitesi, üretim uzmanlığı, müşteri odaklılığ 1 , yenilikçilik gibi unsurları içeren kurumsal yetkinliği etkilemektedir (Berens, Van Riel ve Rekom, 2007). Ayrıca yapılan çalışmalar müşterilerin satın alma davranışlarını müşterinin kurum ile özdeşleşmesinin de etkilediğini göstermektedir. Bir başka ifadeyle, kurumun müşteriler tarafından algılanan değerleriyle, müşterilerin değerleri arasında uyum olduğunda, müşterilerin o işletmeye ya da o işletmenin ürünlerine yönelik bağl1lı̆̆1 ve satın alma davranış1 da artabilmektedir.

Ancak bir işletmenin itibarını yönetmek hiç de kolay değildir. Son dönemlerde müşterilerin kendi aralarında ve işletme ile kolaylıkla irtibata geçebilmeleri olumlu yönlerinin yanında olumsuz bazı sonuçlar da doğurmuştur. Bunlardan en önemlisi işletme hakkında çıkan olumsuz haberlerin hızlı bir şekilde yayılması ve oluşan olumsuz tanınırlığın işletme hakkındaki müşteri algısını etkilemesidir (Dawar ve Pillutla, 2000). Örnek olarak, yapılan araştırmalara göre işletmelere veyahut ürünlerine yönelik müşteriler nezninde herhangi bir olumsuz bir duyum oluştuğunda, müşterilerin satın alma davranışı olumsuz yönde değişebilmektedir (Um, 2013). Bir başka ifadeyle, müşterilerin işletmelere yönelik olumsuz bilgiye sahip olmaları işletmeler üzerinde yıkıcı bir etkiye sebebiyet verebilir. Ancak yine yapılan çalışmalar özellikle krizlerde kurumsal itibarın değerini de vurgulamaktadır (Fombrun, Van Riel ve Van Riel, 2004). Bu sebeple işletmeler müşterilerin kendilerine yönelik olumlu bir algıya sahip olmalarını önemsemekte ve ürün, fiyat, dağıtım gibi pazarlama karması elemanlarına ek olarak günümüz 
iletişim çağında yaşanan gelişmeler doğrultusunda çeşitli iletişim araçlarından yararlanarak bu algıyı yönetmeye ve müşterilerin satın alma kararlarını olumlu yönde etkilemeye çalışmaktadır.

$\mathrm{Bu}$ bağlamda müşterilerin satın alma niyetleri incelendiğinde fiyat, ürün ve benzeri faktörlerin yanında işletme davranışlarının müşterideki etkisini inceleyen çalışmalar literatürde sıklıkla yer almaktadır (Creyer, 1997). Bu çalışmada, önceki çalışmaların aksine ve farklı olarak, üç şekilde literatüre ve firmalara fayda sağlanması hedeflenmiştir. Öncelikle, işletme ve ürünleri açısından olumlu çağrışımlar oluşturulması ve bu çağrışımların desteklenmesi stratejisinin sonucu olarak müşterilerin zihinlerinde yer bulan kurumsal yetkinlik kavramı (Brown ve Dacin, 1997) ile müşteri satın alma niyeti arasındaki ilişki incelenmektedir. Kurumsal yetkinlik kavramı işletme itibarı açısından önem teşkil eden bir olgudur ve müşterilerde satın almayı tetikleyeceği düşünülmektedir (Marquina ve Morales, 2012; Zarei ve Maleki, 2018). Ancak literatürde bu ilişkiyi inceleyen kısıtlı sayıda çalışma bulunmaktadır. Buna ek olarak, bu çalışmalar iki kavram arasındaki direk ilişkiyi incelemektedir. Oysaki, günümüzde konusunda yetkin olarak algılanan birçok firmanın hedef kitleleleri tarafından çevrelerine vermek istedikleri imaja uymamaları sebebi ile ya da duyulan olumsuz bir haber sebebi ile tercih edilmedikleri bir gerçektir. Dolayısıyla bu çalışmada işletme imajı ile müşteri imajı arasındaki uyumdan oluşan müşterikurum özdeşleşmesinin önemi vurgulanmak istenmektedir. Son dönemde önem kazanan bir diğer konu ise olumsuz haberlerin müşteri kurum ilişkisine etkisidir. Olumsuz haberlerin müşteri satın alma isteğine olumsuz etkisi olduğu tartışma götürmezdir (Zhu ve Chang, 2012). Ancak müşterilerin bu haberleri nasıl algılayıp yorumladıkları ve kendileri tarafından yetkin bulunan bir firmada satın alma niyetleri üzerinde ne seviyede etkili olacağ literatürde tartışılan önemli bir konudur (Sohn ve Lariscy, 2015). Dolayısıyla bu çalışmada kurumsal yetkinlik ve satın alma niyeti arasındaki ilişkide müşteri kurum özdeşleşmesinin ve olumsuz tanınırlığın rölü üzerinde durulmakta ve gerek literatüre gerekse firmalara katkı sağlanması amaçlanmaktadır.

\section{Literatür Taraması}

\subsection{Kurumsal Yetkinlik}

Kurumsal yetkinlik (corporate ability), "işletmenin çıtılarının üretim ve teslimindeki uzmanlığıdır" (Assiouras, 2012, s. 145; Berens ve diğerleri, 2007, s. 234; Brammer, Hongwei ve Kamel, 2015, s. 326; Feldman ve Vasquez-Parraga, 2013, s. 102; Kim, 2013 :158; Kim, Kim ve Sung, 2014, s. 344; Walsh ve Bartikowski, 2013, s. 989; Zhou, Poon ve Huang, 2012, s. 46). Literatürde ilk olarak Brown ve Dacin (1997) tarafından işletmenin oluşturduğu çağrışımlar altında bahsedilen kurumsal yetkinliği, Luo ve Bhattacharya (2006) ise bir işletmenin hali hazırda pazara sunduğu ürünlerinin kalitesini arttırma ya da ürünlerde yenilikler oluşturma açısından uzmanlığı ve yeterliliği olarak tanımlamıştır. Daha geniş bir başka ifadeyle ise kurumsal yetkinlik, bir işletmenin çok çeşitli özelliklerini özetleyen soyut boyutlar toplamıdır. Bu özellikler arasında, çalışanların uzmanlıkları, işletmenin üretim uzmanlığı, ürün kalitesi, müşteri odaklılılı̆̆ı, yenilikçiliği, araştırma ve geliştirmede uzmanlığı ve satış sonrası servise yönelik hizmetleri bulunmaktadır (Becker-Olsen, Cudmore ve Hill, 2006; Berens ve diğerleri, 2007; Feldman ve Vasquez-Parraga, 2013; Kim, 2013; Xie, 2014). Brown ve Dacin (1997)'e göre ise kurumsal yetkinlik tüketici davranışlarını olumlu yönde etkilemekte sosyal sorumluktan dahi daha etkilidir.

İşletmelerin kurumsal yetkinliklerini kavramsallaştırmak ve işlevselleştirmek için birçok çerçeve mevcut olsa da, genel olarak işletmenin ürün üretme ve sunma konusundaki uzmanlığını tanımlayan üç temel özellik benimsenmiştir. Bunlar: ürün kalitesi, teknolojik inovasyon ve sektördeki liderliktir (Feldman ve Vasquez-Parraga, 2013). Bu özelliklere sahip olan ve dolayısıyla müşteriler ve kamuoyu tarafindan kurumsal yetkin olarak algılanan işletmelerin ürünlerine güvenildiği ve müşterilerin bu işletmeleri kendilerine yakın gördükleri söylenebilir (Lin, Chen, Chiu ve Lee, 2011). Müşteriler işletmelerin kurumsal yetkinliği ile ilgili bilgilere, işletme raporları, medya ve online kanallardan erişebilmekte ve böylece işletmenin yetkinliği hakkındaki algılarını oluşturabilmektedirler (Zhou ve diğerleri, 2012). 
Bunun yanı sıra, kurumsal yetkinlik işletmelerde, özellikle çalışanlar açısından tehlikesiz, güvenli ve rahat bir ortam sağlanması olarak da değerlendirilmektedir (Brammer ve diğerleri, 2015). Bu sebeple kurumsal yetkinlik, kişilerin iş teklifini kabul etme kararlarını dahi etkilemektedir. Bir başka ifadeyle, kişiler kurumsal yetkinliğinin düşük olduğu işletmelerde iş güvenliğinin olmadığını ya da özsaygılarının olmayacağını düşünerek iş tekliflerini kabul etmeyebilirler (Berens ve diğerleri, 2007).

Aynı zamanda, kurumsal yetkinlik işletmelerin küresel başarısı ve sektörel liderlikleri hakkında da mesajlar içerir (Kim ve diğerleri, 2014). Bir işletmenin kurumsal yetkinlikleri hakkında sahip olunan bilgi, sadece müşterilerin satın aldıkları ürünlere yönelik müşterilerin satın alma davranışlarını etkilemez. İşletmenin genel olarak değerlendirilmesinde de önemli bir etki yaparak (Brown ve Dacin,1997), o işletmenin hisse senedinin alınıp alınmamasına ya da o işletmeye iş başvurusu yapılıp yapılmamasını da etki eder. Örneğin bir yatırımcı, risk almamak için işletmenin kurumsal yetkinlikleri doğrultusunda yatırım kararını verir. Bu sebeple yatırım yapmak istediğinde, bulunduğu hizmet kolu ve sunduğu ürünlerde yeterince yetkin olarak gördüğü işletmeye yatırım yapmayı tercih eder. Dolayısıyla işletmelerin kurumsal yetkinlikleri, işletmelerin finansal performanslarını dolaylı yollardan da etkilemektedir (Berens ve diğerleri, 2007; Becker-Olsen ve diğerleri, 2006; Xie, 2014).

\subsection{Müşteri Kurum Özdeşleşmesi}

Tajfel (1978) sosyal kimliğin, sosyal gruplar ya da kişinin sosyal grup üyeliği üzerinden şekillenen ve bu üyelik doğrultusunda oluşan değer ve duygusal önemlerle birlikte kişinin benliğinin bir parçası olduğunu belirtmektedir. Turner (1985) tarafından geliştirilen Kendini Kategorilendirme Teorisi (Self-categorization Theory) ile Sosyal Kimlik Teorisi (Social Identity Theory) (Tajfel ve Turner, 1985) kapsamında bireyin sosyal olarak kendini ve çevresini tanımlaması sonucu aralarında oluşan olumlu bağı aktaran özdeşleşme kavramı literatürde çeşitli şekillerde sıkça yer bulmuştur. Kavramın ilk kullanıldığı şekillerinden biri olan örgütsel özdeşleşme, örgütsel davranış teorisi altında örgüt ile çalışan arasında "başarı ve başarısızlık durumlarını da içeren, ait olma ya da birlik olma algılayışı" (Ashforth ve Mael, 1989, s. 23) olarak tanımlanmıştır. Cheney ve Tompkins $(1987$, s. 6)'e göre kimlik uyumunu ifade eden ve "örgütün amaçlarıyla bireysel amaçların bütünleştiği bir süreç" (Hall, Schneider ve Nygren, 1970) olan örgütsel özdeşleşme durumunda kişi çalıştığı örgüt ile kendini bir bütün olarak görmekte ve kendi kimliğini bu örgütün kimliği ile tanımlamaktadır (Mael ve Ashforth, 1992). Bu olumlu kimlik bütünlenmesi sonucunda, kişi kendi hakkında da daha olumlu değerlendirmeler yapmakta ve bu durum kişinin kendine olan saygısını da olumlu yönde etkilemektedir (Wegge, Van Dick, Fisher, Wecking ve Moltzen, 2006).

Örgütsel özdeşleşmeden yola çıkarak kavram, müşteri-kurumarasındaki özdeşdeşmeye aktarılmış ve kimliği müşteri tarafından değerlendirildiğinde cazip bulunan işletmeler ile müşteriler arasında özdeşleşme (consumer-company identification) olduğu öngürülmüştür (Dutton, Dukerich ve Harquail, 1994; Keh ve Xie, 2009). Bhattacharya ve Sen (2003)'e göre kişilerin bir işletme ile özdeşleşmeleri için o işletmede çalışmalarına gerek yoktur. Edwards ve Peccei (2007, s. 26)'ye göre örgütsel özdeşleşme kavramı "duygusal ve bilişsel" olarak algılanan bir bağdır. Aynı şekilde müş̧eriler de işletme ile "duygusal ve bilişsel" bağlar kurmaktadırlar. Aherne, Bhattacharya ve Gruen (2005)'nin çalışmasında bahsedildiği üzere, müşteriler işletmelerin imajlarını pazara sundukları ürünler, satış elemanları, kültür ve benzeri şekilde algılanan işletme özellikleri üzerinden değerlendirip bunun sonucunda olumlu sonuçlar elde ettiklerinde özdeşleşme gerçekleşmektedir. Ayrıca yine aynı yazarlara göre, müşteri ile işletme ve ürünleri arasında sık temas olduğunda müşteriler kendilerini işletmeye daha yakın hissetmekte ve kolay özdeşleşmektedirler. Örgütsel özdeşleşmenin çalışanların bağlılığına, ekstra rol davranışı ve ekstra performansa etkisi olması gibi (Van Knippenberg, Van Dick ve Tavares, 2007), müşteri-kurum arasında yaşanan duygusal özdeşleşmede de müşterilerin, bağl1lık (Keh ve Xie, 2009) ve satın almaya (Aherne vd., 2005) ek olarak kendilerinden beklenmeyen olumlu 
davranışlar sergiledikleri saptanmıştır (Devrani ve Tüzün, 2008; Keh ve Yie, 2009; Lii ve Lee, 2012).

\subsection{Algilanan Olumsuz Duyurum}

Duyurum (publicity), güvenilen bir bilgi kaynağından gelen bilgileri ifade eder (Ahluwalia, Burnkrant ve Unnava, 2000; Gendel-Guterman ve Levy, 2017). Olumsuz duyurum (negative publicity) ise haberlerde çıkan genel anlamda kötü bilgilerdir (Hoye ve Lievens, 2005; Liu, Lischka ve Kenning, 2018). Bu bağlamda, kavram "bir ürün, hizmet, iş birimi ya da bireyle ilgili basılı ya da yayın organları ya da ağızdan ağıza gelen sözlerle zararlı haberler sunarak olumsuz bilgilerin dağıtılması"dır (Chung ve Jiang, 2017, s. 268). Olumsuz duyurumlar, performans odaklı ya da değer odaklı olmak üzere iki şekilde sınıflandırılandırılmaktadır. Performans odaklı olumsuz duyurum, bir işletmenin ürün arızası gibi işlevsel niteliklerini içerirken; değer odaklı olumsuz duyurum ise işletmenin genel müdürünün özel hayatına ilişkin olumsuz yaşantısı gibi sosyal ya da etik sorunları içerir (Chung ve Jiang, 2017; Pullig, Netemeyer ve Biswas, 2006). Olumsuz duyurumun etkileri ise içsel ve dişsal olmak üzere iki şekilde ele alınmaktadır. Ürünün kusurlu olması ya da yanlış pazarlama stratejileri içsel nedenlerden kaynaklı olumsuz duyuruma sebep olurken; işletmenin kontrolü dışında olan nedenlerden kaynaklı olumsuz duyurum ise dışsal olumsuz duyuruma sebep olmaktadır (Chung ve Jiang, 2017).

Algilanan olumsuz duyurum (perceived negative publicity) ise bu duyurumun nas1 algılandığıdır ve insanların hem kendi hem de başkalarının davranışlarını nasıl açıkladığını belirtmeye çalışan atıf teorisine dayanmaktadır (Gendel- Guterman ve Levy, 2017). İşletmenin tüm paydaşları, işletmenin yaşadığı olaylardan ve basından elde ettikleri bilgilerle kendi var olan bilgileri doğrultusunda değerlendirerek duyurum hakkında olumlu veyahut olumsuz bir algiya sahip olurlar (Zhu ve Chang, 2012). Dolayısıyla bazıları bilgi olumsuz olduğu halde bunu olumlu olarak algılayabilirken diğerlerinin duyurum ve dolayısıyla işletme veya ürünleri hakkındaki algısı olumsuz olabilir. Başka bir ifadeyle, algılanan olumsuz duyurum müşterilerin bir işletmeyi ve ürünlerini genel olarak değerlendirken sahip olduğu olumsuz bilgileri algılama şeklidir (Ahluwalia ve diğerleri, 2000). Müşterilerin işletmelere yönelik olumsuz duyurumlar sonucu oluşan algıları sadece işletme ve ürünleriyle sınırlı kalmaz. Aynı zamanda insan kaynakları, finans, muhasebe, araştırma geliştirme gibi işletmenin diğer tüm fonksiyonlarına yönelik de olabilir (Ahluwalia ve diğerleri, 2000). Bu sebeple işletmelere yönelik olumsuz yorumlar, mesajlar ya da söylentiler işletmelerin ürünlerinin algısına zarar vermekte ve müşterinin satın alma isteğini ve işletmelerin satışlarını azaltmaktadır (Berger, Sorensen ve Rasmussen, 2010). Bunun yanı sıra, müşterilerin maruz kaldıkları olumsuz duyurumların etkisinin olumlu olanlar ile kıyaslandığında çok daha fazla olacağ 1 görülmektedir (Ahluwalia ve diğerleri, 2000; Berger ve diğerleri, 2010; Chung ve Jiang, 2017; Dean, 2004; Gendel-Guterman ve Levy, 2017; Menon, Sorensen ve Rasmussen, 1999).

\subsection{Satın Alma Niyeti}

Satın alma niyeti (purchase intention), müşterilerin belirli bir ürün ya da hizmeti alma olasılığna verilen addır. Niyet sözkonusu olduğu için gerçek satın almadan değil daha sonra gerçekleşebilecek olan olası satın alma konusunda müşterinin düşüncesini belirtmektedir. Planlı Davranış Teorisinde (Theory of Planned Behavior) (Fishbein ve Ajzen, 1975) ifade edildiği üzere, niyetler sonucunda davranışlar oluşur. Satınalmanın gerçekleşmesinden önce satınalma niyetinin önemli bir belirleyici olarak kabul edilip edilemeyeceği alanyazında tartışılmasına rağmen, literatürde gerçekleşen satın alma yerine ve gelecekte olası beklenen satın almayı göstermesi açısından satın alma niyeti sıklıkla kullanılmaktadır (Kalwani ve Silk, 1982; Sun ve Morwitz, 2010). 


\section{Araştırmanın Modeli ve Hipotezleri}

Kurumsal yetkinlik ile satın alma niyeti arasındaki ilişkiyi değerlendiren son dönemdeki çalışmalarda, işletmelerin ürünleri ve pazara sundukları değer açısından müşteri tarafından yetkin olarak algılanmasının satın almayı önemli ölçüde etkilediği tespit edilmiştir (Marquina ve Morales, 2012; Zarei ve Maleki, 2018). Bunun yanı sıra, bir işletmenin genel imajının müşterinin satın alma niyetine olan etkisini inceleyen çalışmalar da alanyazında sıklıkla yer bulmaktadır (Buckley, 1991). Bu çalışmalarda, müşterilerin işletmelerin sundukları değerler üzerinden işletmelerin imajını değerlendirdikleri ve bunun sonucunda ürün alıp almamaya karar verdikleri sonucuna varılmıştır (Dodds, Monroe ve Grewal, 1991; Grewal, Monroe ve Krishnan, 1998). Dolayısıyla kurumsal yetkinliğin işletmeler ile ilgili müşterilerin zihninde oluşan çağrışımların içerisinde yer aldığı ve bu çağrışımların müşterilerin ürünler hakkındaki değerlendirmelerini etkilediğini söylemek mümkündür (Brown ve Dacin, 1997; Gürhan-Canli ve Batra, 2004). Ayrıca, bireysel imaj ile satın alınan ürün ve/veya işletmenin arasındaki imaj uyumunun müşteri tercihleri üzerine etkisi de yine literatürde yer bulan bir konudur (Choi ve Huddleston, 2013; Grubb ve Hupp, 1968). Alanyazında belirtildiği üzere, müşteri kurum özdeşleşmesi, müşteri ve işletme arasındaki kimlik değerlendirmesi sonucunda müşterinin kendini işletme ile bir tutması halidir. $\mathrm{Bu}$ özdeşleşme sonucunda müşteriler kendilerini işletmeye daha yakın hissetmekte ve bu işletmenin ürünlerini diğer ürünlere oranla daha çok tercih etmekte ve gerekirse daha yüksek ücret ödemeyi kabul etmektedirler (Cornwell ve Coote, 2005; Keh ve Yie, 2009). Aynı zamanda, eğer müşteriler mal ya da hizmet aldıkları işletmelerin yetkin ya da uzman olduklarını düşünüyorlarsa, o işletmenin ürünlerini satın alma eğilimleri de artacaktır (Marquina ve Morales, 2012; Zarei ve Maleki, 2018). Bu bağlamda, müşterilerin yetkin olarak algıladıkları bir örgüt ile özdeşleşmek isteyecekleri ve bu özdeşleşmenin de satın alma niyetini olumlu yönde etkileyeceği düşünülmektedir. Bu doğrultuda araştırmanın ilk hipotezi aşağıdaki şekilde kurulmuştur

$\mathbf{H}_{1}$ : Müşteri kurum özdeşleşmesinin kurumsal yetkinlik ve satın alma niyeti arasındaki ilişkide aracılık etkisi vardır.

Literatür incelendiğinde, müşterilerin işletmeye yönelik olumsuz duyurumlara maruz kalmalarının o işletmenin ürünleri ile ilgili satın alma kararı verdikleri esnada olumsuz yönde etkili olacağı görülmektedir (Ahluwalia ve diğerleri, 2000; Berger ve diğerleri, 2010; Chung ve Jiang, 2017; Dean, 2004; Gendel-Guterman ve Levy, 2017; Menon ve diğerleri, 1999). Olumsuz bir bilginin olumlu bir bilgi ile karşılaştırıldığ ında tüketiciler üzerinde beş kat daha etkili olduğu düşünülmektedir. Hatta bazı çalışmalara göre bu durum bağlılığı yüksek olan müşteriler için bile söz konusudur (Berger ve diğerleri, 2010; Ham, Cho ve Woo, 2012; Griffin, Babin ve Attaway, 1991; Um, 2013). Bunun yanı sıra, müşterilerin işletmelere yönelik olumsuz duyurumları dikkate almaları olumsuz bir algı yaratmakla kalmamamakta, müşterilerin işletmenin kurumsal yetkinliğine yönelik de olumsuz tutuma sahip olmalarına neden olmaktadır (Lin ve diğerleri, 2011; Tsai, Lin, Ma ve Wang, 2015). Bu bağlamda, olumsuz duyurumlar aynı zamanda müşterilerin işletmeye yönelik algılarını da etkileyerek satın alma niyetlerini olumsuz yönde etkileyeceği düşünülmektedir. Daha önce alanyazında da belirtildiği üzere, müşterilerin işletme hakkında olumsuz duyurum algısına sahip olmasının nedenleri arasında işletme hakkında olumsuz bilgiye sahip olmaları ya da işletme hakkında olumlu bilgiden fazla olumsuz bilgiye sahip olmaları sayılabilir. Bu sebeple daha önce işletme hakkında olumlu bilgiye sahip olan müşteriler eğer olumsuz duyurumu olumsuz algilamaz ya da yeterli seviyede önemli bulmaz ise hala aynı işletmenin ürünlerini almayı düşünebilirler. Oysaki, aynı olumsuz duyurum yeterince negatif olarak algılanır ise yine aynı müşteri bu işletmenin ürününü almaktan vazgeçebilir. $\mathrm{Bu}$ doğrultuda araştırmanın ikinci hipotezi şu şekilde kurulmuştur.

$\mathbf{H}_{2}$ : Algilanan olumsuz duyurumun kurumsal yetkinlik ve satın alma niyeti arasındaki ilişkide düzenleyici etkisi vardır.

Alanyazın doğrultusunda oluşturulan araştırma modeli aşağıda gösterilmiştir. 


\section{Şekil 1. Araştırma modeli}

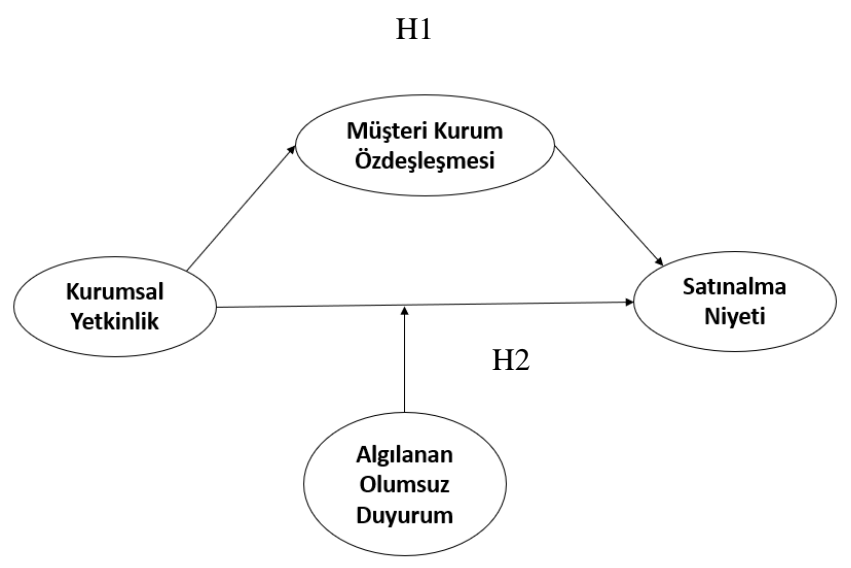

\section{Araştırmanın Amacı ve Önemi}

Araştırmanın amacı kurumsal yetkinlik ve satın alma niyeti arasındaki ilişkiyi güçlendirecek ve/veya azaltabilecek kavramlar üzerinden bir çalışma yürüterek alanyazına katkı sağlamaktır.

\section{Yöntem}

\subsection{Değişkenlere İlişkin Ölçme Araçları}

Çalışmada kullanılan ulusal ve uluslararası yazında geçerliliği ve güvenilirliği kanıtlanmış ölçekler detaylı bir literatür taramasından sonra belirlenmiş ve anket formu iki bölüm olacak şekilde şekillendirilmiştir. İlk bölümde katılımcıların yaş, cinsiyet, medeni durum ve aylık gelirlerini belirlemeye yönelik ifadelerden oluşan demografik sorulara yer verilmiştir. Takip eden bölümde çalışmanın modelinde bağımsız değişken olarak belirlenen kurumsal yetkinlik Berens, Van Riel ve Van Bruggen (2005) tarafından önerilen 5 soru ile, bağımlı değişken olan satın alma niyeti Lin ve diğerleri (2011) tarafından geliştirilen 4 ifadeli ölçek ile ölçülmüştür. Lin ve diğerleri (2011) bu ölçeği Pavlou, (2003) ve Yoo ve Donthu (2001)'den esinlenerek geliştirmiştir. Müşteri kurum özdeşleşmesi için ise Lin ve diğerleri (2011) tarafından geliştirilen 5 ifadeli ölçekten yararlanılmıştır. Algılanan olumsuz duyurum Dawar ve Pillutla (2000) tarafindan geliştirilen 3 ifadeli ölçek ile ölçülmüştür. Tüm ölçekler 5'li likert ölçeğine göre (1) Kesinlikle Katılmıorum'dan (5) Kesinlikle Katılıyorum'a derecelendirilmiştir. Modelde yer alan değişkenleri ölçmek için kullanılan ifadeler ayrıca Tablo 1'de verilmiştir. Cevaplayıcıların ifadeleri daha rahat anlayabilmeleri için modelde bulunan tüm kavramların daha iyi algılanabileceği düşünülen ve anketin yapıldığı dönemden kısa bir süre önce olumsuz bir duyurum yapmış olan bir otomotiv işletmesi markası anket formunda paylaşı1mış ve ifadeleri o markayı düşünerek değerlendirmeleri istenmiştir.

\subsection{Araştırmanın Kapsamı}

Araştırma kapsamına İstanbul'da bir vakıf üniversitesinde yüksek lisans eğitimi alan ve aynı zamanda çalışma hayatında olan kişiler alınmıştır. Araştırmanın değişkenlerinin tespit edilebilmesi ve araştırmanın sonuçlarının genellenebilmesi için örneklemin çeşitliliğinin uygun olacağı düşünülmektedir. Bir başka ifadeyle, araştırmada ele alınan kavramlar ve kavramların test edildiği işletme dikkate alındığında, anket formunun farklı işletmelerde ve farklı sektörlerde çalışan, farklı geçmiş ve kültürlerden gelen, yaş, iş tecrübesi, gelir seviyesi gibi demografik açıdan farklılık gözeden katılımcılar tarafından cevaplanmasının geniş bir çeşitlilik oluşturacağı ve araştırma sonuçlarını zenginleştireceği düşüncesiyle yüksek lisans öğrencileri araştırma kapsamına alınmıştır. Araştırmanın yüksek lisans seviyesinde yapılmasının bir diğer sebebi de bahsi geçen işletme ile ilgili olumsuz duyurumun bu kitle tarafından takip edildiği düşüncesidir. 
Bu bağlamda bahsi geçen üniversitede 2018 yaz dönemi yüksek lisans programına 722 öğrencinin kaydolduğu bilgisi edinilmiştir. Ana kütle üzerinden örnek kütle hesabına göre 772 örnek büyüklügünün $\% 95$ güven sinırları içerisinde ve $\% 5$ anlamlılık düzeyinde 251 olduğu hesaplanmıştır. Araştırma kapsamında kolayda örneklem metodu ile ulaşılan katılımcı sayısı ise 313’tür. Anket yöntemi kullanılan bu çalışmada veriler araştırmacılar tarafından sınıf ortamında dağıtılarak elde edilmiştir.

\section{Bulgular}

\subsection{Demografik Özelliklere Yönelik Bulgular}

Araştırma kapsamına alınan 313 katılımcının ortalama yaşının 28,7 olduğu, standard sapması 7 olan katılımcıların yaşının 19 ile 52 arasında değiştiği saptanmıştır. Ayrıca katılımcıların diğer demografik değerlerine göre $\% 55,8$ 'i kadındır. Katılımcıların gelir düzeyleri incelendiğinde ise \%41'inin 3000€ ve alt1, \%30'unun 3001€-5000€ arasında, \%29'unun ise 5001€ ve üzeri aylık gelirlerinin olduğu tespit edilmiştir.

Katılımcıların demografik bilgilerinin analizini takiben SPSS 22 ile veri analizine geçilmiş ve öncelikli olarak tüm ifadelerin ortalama ve standart sapma değerleri elde edilmiştir. $\mathrm{Bu}$ değerler Tablo 1'de gösterilmektedir. Sonrasında ise, analizlere faktör ve güvenilirlik analizleri ve yapısal eşitlik modeli ile devam edilmiştir.

\subsection{Faktör ve Güvenilirlik Analizleri}

Araştırma modelinde yer alan değişkenler öncelikle açımlayıcı faktör analizine sokulmuş ve tüm değişkenler için KMO değeri 0.80 üstü olarak gözlemlendiğinden eldeki veri grubunun faktör analizi için uygun olduğu sonucuna varılmıştır (Durmuş, Yurtkoru ve Çinko, 2011). Açımlayıcı faktör analizinde tüm faktör yükleri en düşük 0.744 ile en yüksek 0.904 arasında değiştiğinden ve faktör yapısı literatür doğrultusunda beklendiği gibi geliştiğinden bir sonraki aşama olan güvenilirlik analizine geçilmiştir. Bu aşamada müşteri kurum özdeşleşmesi ölçeğinin Cronbach Alfa değerinin var olan değerden daha güvenilir bir seviyeye yükseltilmesi için ölçeğin ilk sorusu analizden çıkarılmış ve faktör analizi ve güvenilirlik analizi tekrarlanmıştır. Güvenilirlik analizi sonucunda elde edilen değerler tüm ölçeklerin oldukça güvenilir olduğunu göstermektedir (Durmuş ve diğerleri, 2011). Faktör ve güvenilirlik analizi sonuçları Tablo 1'de verilmiştir. $\mathrm{Bu}$ değerler doğrultusunda AMOS 22 kullanılarak doğrulayıcı faktör analizi ve yapısal eşitlik modeli ile analizlere devam edilmiştir. 
Tablo 1. Değişkenler ve ölçme araçlarına ait bulgular

\begin{tabular}{|c|c|c|c|c|c|c|c|c|}
\hline $\begin{array}{l}\text { Değişk } \\
\text { enler }\end{array}$ & Sorular & Ortalama & $\begin{array}{l}\text { St. } \\
\text { Sapma }\end{array}$ & $\begin{array}{l}\text { Açımlayı } \\
\text { cı } \\
\text { Faktör } \\
\text { Analizi } \\
\text { Yükleri }\end{array}$ & $\begin{array}{l}\text { Açıklana } \\
\text { n } \\
\text { Varyans }\end{array}$ & $\begin{array}{l}\text { Cronbac } \\
\text { h Alfa } \\
\text { Değeri }\end{array}$ & $\begin{array}{l}\text { Doğrula } \\
\text { yıcı } \\
\text { Faktör } \\
\text { Analizi } \\
\text { Yükleri }\end{array}$ & AVE \\
\hline \multirow{4}{*}{$\begin{array}{l}\text { Satın } \\
\text { Alma } \\
\text { Niyeti }\end{array}$} & $\begin{array}{l}\text { "Eğer satın alma olanağı } \\
\text { verilse xxxx markasından } \\
\text { araba satın alırım." }\end{array}$ & 3,96 & 1,13 & 0,851 & \multirow{4}{*}{$\% 71$} & \multirow{4}{*}{0.862} & 0,931 & \multirow{4}{*}{$\% 58$} \\
\hline & $\begin{array}{l}\text { "Ĕger satın alma olanağı } \\
\text { verilse gelecekte xxxx } \\
\text { markasından araba satın } \\
\text { alırım." }\end{array}$ & 3,88 & 1,10 & 0,851 & & & 0,951 & \\
\hline & $\begin{array}{l}\text { "Muhtemelen yakın } \\
\text { gelecekte xxxx } \\
\text { markasından araba satın } \\
\text { alacağım." } \\
\end{array}$ & 2,78 & 1,22 & 0,833 & & & 0,521 & \\
\hline & $\begin{array}{l}\text { "Yakın gelecekte xxxx } \\
\text { markasından araba satın } \\
\text { alırım diye düşünüyorum." }\end{array}$ & 2,93 & 1,23 & 0,833 & & & 0,541 & \\
\hline \multirow{2}{*}{$\begin{array}{l}\text { Kuru } \\
\text { msal } \\
\text { Yetkin } \\
\text { lik }\end{array}$} & $\begin{array}{l}\text { "xxxx’in yenilikçi ürün ve } \\
\text { hizmetler geliştirdiğini } \\
\text { düşünüyorum." }\end{array}$ & 3,68 & 0,91 & 0,766 & \multirow{2}{*}{$\% 59$} & \multirow{2}{*}{0.826} & 0,702 & \multirow{2}{*}{$\% 49$} \\
\hline & $\begin{array}{l}\text { "xxxx'in pazara yüksek } \\
\text { kaliteli ürünler sunduğunu } \\
\text { düşünüyorum." }\end{array}$ & 3,75 & 1,07 & 0,836 & & & 0,802 & \\
\hline $\begin{array}{l}\text { Müşte } \\
\text { ri } \\
\text { Kuru } \\
\text { m } \\
\text { Özdeşl } \\
\text { eşmesi }\end{array}$ & $\begin{array}{l}\text { "xxxx hakkında } \\
\text { başkalarıyla konuşurken } \\
\text { güçlü bir aidiyet } \\
\text { hissederim." }\end{array}$ & 3,04 & 1,29 & $\begin{array}{l}\text { Analizde } \\
\mathrm{n} \\
\text { çıkartıldı }\end{array}$ & $\% 70$ & 0.853 & & \\
\hline \multirow{5}{*}{$\begin{array}{l}\text { Müşte } \\
\text { ri } \\
\text { Kuru } \\
\text { m } \\
\text { Özdeşl } \\
\text { eşmesi } \\
\text { Algila } \\
\text { nan } \\
\text { Olums } \\
\text { uz } \\
\text { Duyur } \\
\text { um }\end{array}$} & $\begin{array}{l}\text { "Diğer şirketlerle } \\
\text { karşlaştırdığımda xxxx'ın } \\
\text { ürünlerini tercih ederim." }\end{array}$ & 3,27 & 1,16 & 0,819 & \multirow{5}{*}{$\begin{array}{l}\% 70 \\
\% 77\end{array}$} & \multirow{5}{*}{$\begin{array}{l}0.853 \\
0.852\end{array}$} & 0,811 & $\% 56$ \\
\hline & $\begin{array}{l}\text { "xxxx'in kurum imaj1 } \\
\text { hakkında olumluyum." }\end{array}$ & 3,71 & 1,05 & 0,836 & & & 0,818 & \multirow{4}{*}{$\begin{array}{l}\% 56 \\
\% 67\end{array}$} \\
\hline & $\begin{array}{l}\text { "xxxx'in çalışanlarının } \\
\text { servis verirkenki tutumları } \\
\text { ile kendimi } \\
\text { özdeşleştiririm." }\end{array}$ & 3,12 & 0,94 & 0,837 & & & 0,657 & \\
\hline & $\begin{array}{l}\text { "xxxx’in yönetim anlayışı } \\
\text { ile kendimi } \\
\text { özdeşleştiririm." }\end{array}$ & 3,05 & 1,03 & 0,849 & & & 0,699 & \\
\hline & $\begin{array}{l}\text { "xxxx ile ilgili olumsuz } \\
\text { haberlerin önemli } \\
\text { olduğunu hissediyorum." }\end{array}$ & 3,45 & 1,18 & 0,829 & & & 0,69 & \\
\hline \multirow{2}{*}{$\begin{array}{l}\text { Algila } \\
\text { nan } \\
\text { Olums } \\
\text { uz } \\
\text { Duyur } \\
\text { um }\end{array}$} & $\begin{array}{l}\text { "xxxx ile ilgili haberler } \\
\text { bana ürünlerinin birçok } \\
\text { risk barındırdı̆̆ını } \\
\text { hissettiriyor." }\end{array}$ & 2,92 & 1,22 & 0,904 & \multirow[b]{2}{*}{$\% 77$} & \multirow[b]{2}{*}{0.852} & 0,884 & \multirow[b]{2}{*}{$\% 67$} \\
\hline & $\begin{array}{lr}\text { Olumsuz } & \text { haberlerin } \\
\text { xxxx'in ürünleri ile ilgili } \\
\text { kalite sorunlarını tamamen } \\
\text { açığa } & \text { çıarttı̆ı̆ını } \\
\text { hissediyorum. } & \\
\end{array}$ & 2,96 & 1,20 & 0,901 & & & 0,863 & \\
\hline
\end{tabular}




\subsection{Doğrulayıcı Faktör ve Yapısal Eşitlik Modeli Analizleri}

Yapılan analizlere göre, doğrulayıcı faktör analizi sonuçları açımlayıcı faktör analizi sonuçlarını destekler niteliktedir. Tüm faktör analizi yükleri istenen değerlerin üstündedir $(>0,5)$ (Hair, Black, Babin ve Anderson, 2014). Ayrıca her bir değişken için açıklanan ortalama varyans (Average variance extracted-AVE) değerleri hesaplanmış ve değerlerin genel olarak beklenen değerlerin üstünde olduğu görülmüştür (Hair ve diğerleri, 2014). Kurumsal yetkinlik için elde edilen değer beklenen seviyede $(0.5)$ olduğu ve uyum iyiliği endeksleri $(\chi 2=250,650 ; \mathrm{df}=91$; $\mathrm{p}=0,000 ; \mathrm{TLI}=0,935 ; \mathrm{IFI}=0,951 ; \mathrm{CFI}=0,950)$ de modeli desteklediği için analize devam edilmiştir. Doğrulayıcı faktör analizi yükleri ve AVE değerleri Tablo 1'de sunulmuştur.

Yapısal eşitlik modeli ile çalışmanın modelinin incelenmesinde Hayes (2013) Model 5 uygulanmıştır. $\mathrm{Bu}$ modelde kurumsal yetkinlik, müşteri kurum özdeşleşmesi ile kurumsal yetkinlik ve müşteri kurum özdeşleşmesinin çarpımından oluşan değer bağımsız değişkenler, satın alma niyeti bağımlı değişken ve müşteri kurum özdeşleşmesi ise aracı değişken olarak kullanılmıştır. Örnek büyüklüğünün yeterliliğini gösteren $\left(\chi^{2} / \mathrm{df}\right)$ değeri ile uyum iyiliği endeksleri (RMR, RMSEA, TLI, IFI, CFI) modelin genel değerlendirmesinin yapılmasını sağlamıştır. AMOS 22 tarafından oluşturulan çıktı (output) dosyasında önerilen "gözlenen değişkenler arasında modifikasyonlar" teori altyapısı da öngörülerek değişiklikler gerçekleştirilmiş ve tüm uyum iyiliği endekslerinin 0,9 değerinden büyük ve kabul sınırları içerisinde olduğu gözlemlenmiş̧tir $\left(\chi^{2}=176,655 ; \mathrm{df}=72 ; \mathrm{p}=0,000 ; \chi^{2} / \mathrm{df}=2,5\right.$, TLI $=0,930$; $\mathrm{IFI}=0,945 ; \mathrm{CFI}=0,945)$. Ayrıca RMR $(0,068)$ ve RMSEA $(0,078)$ değerleri 0,08 'in altındadır ve mükemmel sınırlar dahilinde olmasalar dahi kabul edilebilir değerler çerçevesindedir (Hair ve diğerleri, 2014). Sonuç olarak bulgular, yapısal modelin kabul edilebilirliğini desteklemektedir. Analiz çıktı dosyasından (output) elde edilen bulgular Tablo 2'de sunulmuştur. Aracılık analizinin incelenmesinde Baron ve Kenny (1986: 1176) ve ayrıca Bootstrapping işlemi uygulanmıştır. Edinilen verilere göre; müşteri kurum özdeşleşmesi kurumsal yetkinlik ve satın alma niyeti arasındaki anlamlı ilişkiyi $(0,771 ; \mathrm{p}<0,05)$ anlamsıza $(\mathrm{p}=0,146 ; \mathrm{p}>0,1)$ çevirmiştir. Bu sebeple müşteri kurum özdeşleşmesinin, kurumsal yetkinlik ve satın alma niyeti arasındaki ilişkide tam aracılık rölü etkisi olduğu tespit edilmiştir.

Tablo 2. Yapısal eşitlik modeli aracılık etkisi sonuçları

\begin{tabular}{llll}
\hline Değişkenler Arası İlişki & $\begin{array}{l}\text { Direkt } \\
(\mathrm{p} \text { değeri) }\end{array}$ & $\begin{array}{l}\text { Aracı ile } \\
\text { Direkt } \\
(\mathrm{p} \text { değeri) }\end{array}$ & $\begin{array}{l}\text { Aracı ile } \\
\text { İndirekt } \\
\text { (Bootstrappi } \\
\text { ng) (p } \\
\text { değeri) }\end{array}$ \\
\hline $\begin{array}{l}\text { Kurumsal Yetkinlik } \rightarrow \text { Müşteri Kurum } \\
\text { Özdeşleşmesi }\end{array}$ & $\begin{array}{l}0,863 \\
(0,001)^{*}\end{array}$ & \\
\hline $\begin{array}{l}\text { Müşteri Kurum Özdeşleşmesi } \rightarrow \text { Satın Alma } \\
\text { Niyeti }\end{array}$ & $\begin{array}{l}0,501 \\
(0.001)^{*}\end{array}$ \\
\hline Kurumsal Yetkinlik $\rightarrow$ Satın Alma Niyeti & $\begin{array}{l}0,771 \\
(0,001)^{*}\end{array}$ & & \\
\hline Kurumsal Yetkinlik $\rightarrow$ Satın Alma Niyeti & & $\begin{array}{l}0,161 \\
(0,146)^{* *}\end{array}$ & $\begin{array}{l}0,432 \\
(0,001)^{*}\end{array}$ \\
\hline
\end{tabular}

$* \mathrm{p}<0,001$ seviyesinde anlaml ${ }^{* *} \mathrm{p}>0,1$ seviyesinde anlamlı değil

Algılanan olumsuz duyurumun düzenleyici etkisi incelendiğinde ise satın alma niyetini negatif yönde etkilediği ve de kurumsal yetkinlik ve satın alma niyeti arasındaki ilişkiyi azalttığı, dolayısıyla kurumsal yetkinlik ile satın alma niyeti arasındaki ilişkide algılanan olumsuz duyurumun olumsuz yönde düzenleyicilik etkisi olduğu tespit edilmiştir. Tablo 3'de yapısal eşitlik modelinden elde edilen değişkenler arası ilişkilere ait değerler sunulmuştur. 
Tablo 3. Yapısal eșitlik modeli düzenleyici etkisi sonuçları

\begin{tabular}{lr}
\hline Değişkenler Arası İlişki & Estimate \\
\hline Kurumsal Yetkinlik $\rightarrow$ Satın Alma Niyeti & $0,771^{*}$ \\
\hline Algılanan Olumsuz Duyurum $\rightarrow$ Satın Alma Niyeti & $-0.304^{* *}$ \\
\hline Kurumsal Yetkinlik X Algılanan Olumsuz Duyurum $\rightarrow$ Satın Alma Niyeti & 0,236 \\
\hline
\end{tabular}

$* \mathrm{p}<0,001$ seviyesinde anlaml $* * \mathrm{p}<0,01$ seviyesinde anlaml ${ }^{* * *} \mathrm{p}>0,1$ seviyesinde anlaml

Tablo 3'de verilen bilgiler Baron ve Kenny (1986) ve Sharma, Durand ve Gur-Arie (1981)'nin düzenleyici analizi yorumlamaları doğrultusunda değerlendirilmiş ve algılanan olumsuz duyurumun kurumsal yetkinlik ve satın alma niyeti arasındaki ilişkide negatif yönde düzenleyici rölü olduğu sonucuna varılmıştır. Bu sonuçlar doğrultusunda araştırmanın her iki hipotezi de kabul edilmiştir.

\section{Tartışma, Sonuç ve Öneriler}

Kurumsal yetkinlik sosyal sorumluluk kavramı ile birlikte işletmelerin itibarını oluşturan kavramlardan biridir (Berens ve Van Riel, 2007; Brown ve Dacin, 1997). Ancak literatüre bakıldığında işletmelerin sosyal sorumlu ya da etik olarak algılanmasının tüketici davranışları üzerine olası etkilerini inceleyen birçok çalışma (Creyer ve William, 1997) olmasına rağmen, kurumsal yetkinlik ile yapılmış olan çalışmalar sınırlıdır. Bu çalışma hem literatürdeki bu boşluğu doldurmayı hem de müşteri kurum özdeşleşmesi ve algılanan olumsuz duyurumun bu ilişkideki rölünü inceleyerek literatüre katkı sağlamayı hedeflemiştir. Bu amaçla İstanbul'da bir vakıf üniversitesinde yüksek lisans eğitimi alan ve aynı zamanda çalışma hayatında olan 313 kişiden veri toplanmış ve teorik yapı doğrultusunda oluşturulan çalışmanın modeli öncelikle açımlayıcı faktör analizi sonrasında ise doğrulayıcı faktör analizi ve en sonunda da yapısal eşitlik modeli ile analiz edilmiştir. Elde edilen verinin teorik yapı ile uyum sağladığ görülmüş ve sonuçların değerlendirilmesi ile çalışmaya devam edilmiştir.

Araştırmanın sonuçlarına incelendiğinde, kurumsal yetkinlik ve satın alma niyeti arasında güçlü bir etki (0.771) bulunduğu gözlemlenmiştir. Müşteri ile kurum arasında kimlik uyumunu belirten müşteri kurum özdeşleşmesi modele dahil edildiğinde ise ilişkiyi anlamsız yöne çevirmesi sebebi ile tam aracı değişken görevi görmekte ve bu model satın alma niyetinin \% 25 'ini açıklamaktadır. Hipotez olarak verilmemiş olsa da sonuçlar kısmında kurumsal yetkinlik ve müşteri kurum özdeşleşmesi arasındaki etkiye $(0,863)$ ve müşteri kurum özdeşleşmesi ve satın alma niyeti arasındaki etkiye (0.501) dair sonuçların iletilmesine yer verilmiştir. Bu bulgular doğrultusunda müşterilerin özellikle ürünleri konusunda yetkin olarak algıladıkları işletmeler ile kendi kimliklerini bir bütün olarak görme eğiliminde olduğu ve bu değerlendirmenin müşterinin işletmenin ürünlerini satın alma konusundaki niyetini önemli ölçüde etkilediği söylenebilir. Benlik Genişlemesi Kuramı (Aron ve Aron, 1986) kapsamında da bahsedildiği üzere, kişiler karşılarındakini onlara katabilecekleri değerler yönünde değerlendirir ve bu değerlendirmenin sonucu olumlu olur ise karşıdakini kendi benliği ile özdeşleştirerek benliğini genişletir. Çalışmanın sonuçları müşteri ve kurumlar arası ilişkide de kurumun yetkinlik seviyesinin değerlendirilmesi sonucunda böyle bir sonuç oluştuğu yönündedir. $\mathrm{Bu}$ bulgular daha önce literatürde farklı bağlamlarda test edilmiş olan kurumsal yetkinlik ve satın alma arasındaki ilişkiyi (Marquina ve Morales, 2012; Zarei ve Maleki, 2018) desteklemekte ve ilerletmektedir. Buna ek olarak, kurumsal yetkinlik ile ilgili müşteride olumlu algılar oluşturmanın sadece satın alma açısından değil özdeşleşme açısından önemi de yadsınamaz. Kişinin kendi benliği ile özdeşleştirdiklerine karşı daha anlayışlı, daha affedici ve daha olumlu düşünce, duygu ve davranışlar beslediği literatürde daha önce tesbit edilmiş olup (Devrani ve Tüzün, 2008; Keh ve Yie, 2009; Lii ve Lee, 2012; Swart, Turner, Hewstone ve Voci, 2011), kurumsal yetkinlik algısının bu süreçteki etkisi de bu çalışma ile vurgulanmıştır. 
Çalışmanın bir diğer bulgusu ise, olumsuz duyurumların kurumsal yetkinlik ve satın alma niyeti arasındaki ilişkiyi olumsuz yönde etkilediği şeklindedir. Olumsuz duyurumlar müşteride olumsuz alg1 yaratmakta ve müşterinin kurumu yetkin görmesinin dahi önemi kalmamaktadır. Daha önceki çalışmalarda işletme hakkında çıkan olumsuz haberlerin işletmenin ürünlerinin satın alınması olasılığını olumsuz yönde etkilediği tesbit edilmiştir (East, Hammond ve Lomax, 2008; Griffin ve diğerleri, 1991). Ancak bu çalışmalarda, olumsuz haberlerin müşteriler tarafindan yetkin olarak algılanan ve pazar payı yüksek olan bir işletmenin ürünlerini satın alınmasına olan etkisi incelenmemiştir. Dolayısıyla bu çalışmada olumsuz duyurumların işletmeler üzerindeki yıkıcı etkisi ortaya çıkmaktadır. Bu bulgular doğrultusunda çalışmanın her iki hipotezi de kabul edilmiştir.

Çalışmanın sonuçları işletmelerin müşterilerde oluşturdukları genel algının önemini ve müşteri satın alma davranışına olan etkisini göstermektedir. Gerek müş̧erilerde oluşan olumlu algının sonucunda gerçekleşen müşteri kurum özdeşleşmesinin olumlu etkisi, gerekse olumsuz duyurumların algısının satın alma niyetine olan olumsuz etkisi bu bilgiyi desteklemektedir. Dolayısıyla işletmelere hedef kitlenin her açıdan inceleyip, ürün ve pazarlama karması açısından müşterinin tatmininin ötesinde, müşterinin olumlu olarak algılayacağı tavır ve tutumlar sergileyerek müşterilerinin özdeşleşmek isteyecekleri bir kimlik ve imaj oluşturmaya yoğunlaşmaları önerilmektedir. Ancak yine de bazı istenmeyen olumsuz gelişmeler gerçekleştiğinde de olumsuz duyurumların oluşturduğu menfi etkiden dolayı, müşteriler işletmelere yönelik olumsuz algıya sahip oldukları takdirde işletmeler paydaşlarından samimi bir şekilde özür dileyerek ve kurumsal sosyal sorumluluk projeleriyle bu algıyı yöneterek bu etkileri olumluya çevirmeye çalş̧abilirler (Chung ve Jiang, 2017; Vanhamme ve Grobben, 2008).

Çalışma sosyal bilimlerde sıklıkla rastlanan kısıtlara sahiptir. Sosyal bilimlerde sıkça rastlanan kısıtlardan ortak yöntem varyansının incelenmesi Harman'ın tek faktör testi ile yapılmış ve faktör analizi ile modelde bulunan tüm boyutlar öz değerleri 1'den yüksek olarak belirlenmiştir (Podsakoff, MacKenzie, Lee ve Podsakoff, 2003). Bu sebeple çalışmada ortak yöntem varyansı kısıtının bulunmadığı sonucuna varılmıştır. Bunun yanında en belirgin kısıt verilerin toplanması için kullanılan örneklemdir ki bu nedenle sonuçlar hakkında genelleme yapılabilmesi için farklı bir örneklem kullanılarak veri toplanması önerilir. Bu kısıta ek olarak, otomotiv sektöründe müşteri kurum özleşleşmesi diğer ürünlere göre daha net görülmektedir. Bu sebeple araştırmanın modelinin incelenmesinde ürünleri beğeni toplayan ve müşteri tarafından yetkin olarak algılandığı varsayılan bir otomotiv işletmesi seçilmiş ve son dönemlerde işletme hakkında çıkan olumsuz haberler doğrultusunda algilanan olumsuz kurumsal duyurumun etkisi değerlendirilmiştir. Türk müşteriler otomotiv sektörü ile ilgili olumlu/olumsuz haberleri son derece dikkatli izlemektedirler. Oysaki başka sektörlerde olumsuz haberler bu kadar dikkat çekmeyebilir veya bu derece olumsuz olarak algılanmayabileceğinden dolayı etkili olmayabilir. Dolayısıyla modelin başka ürün grupları ile tekrar edilmesi de sonuçların güvenirliği açısından önemlidir.

\section{Kaynakça}

Aherne, M., Bhattacharya, C. B. ve Gruen, T. (2005). Antecedents and consequences of customer- company identification: Expanding the role of relationship marketing. Journal of Applied Psychology, 90, 574 -585. doi:10.1037/0021-9010.90.3.574

Ahluwalia, R., Burnkrant, R. E. ve Unnava, H. R. (2000). Consumer response to negative publicity: The moderating role of commitment. Journal of Marketing Research, 37(2), 203214. doi: $10.1509 / j m k r .37 .2 .203 .18734$

Aron, A., ve Aron, E. N. (1986). Love and the expansion of self: Understanding attraction and satisfaction. New York: Hemisphere Publishing Corp/Harper \& Row Publishers.

Ashforth, B.ve Mael, F. (1989). Social identity theory and the organization, Academy of management review, 14(1), 20-40. doi: 10.5465/amr.1989.4278999 
Assiouras, I. (2012). The impact of brand crises on consumer reactions: The role of corporate ability and corporate social responsibility. American Marketing Association, Winter ,145-153.

Baron, R. M., ve Kenny, D. A. (1986). The moderator-mediator variable distinction in social psychological research: Conceptual, strategic and statistical considerations. Journal of Personality and Social Psychology, 51(6),1173-1182. doi:10.1037/0022-3514.51.6.1173

Becker-Olsen, K.L., Cudmore, B.A. ve Hill, R.P. (2006). The impact of perceived corporate social responsibility on consumer behavior. Journal of Business Research, 59, 46- 53. doi: 10.1016/j.jbusres.2005.01.001

Bennett, R. ve Rentschler, R. (2003). Foreword by the guest editors, Corporate reputation review, 6(3), 207-210. doi: 10.1057/palgrave.crr.1540200

Berens, G., Van Riel, C.B. ve Van Bruggen, G.H. (2005). Corporate associations and consumer product responses: The moderating role of corporate brand dominance. Journal of Marketing, 69(3), 35-48. doi: 10.1509/jmkg.69.3.35.66357

Berens, G., Van Riel, C. B. ve Rekom, J.V. (2007). The CSR-Quality trade-off: When can corporate social responsibility and corporate ability Compensate each other?, Journal of Business Ethics, 74, 233-252. doi: 10.1007/s10551-006-9232-0

Berger, J., Sorensen A. T. ve Rasmussen S. J. (2010). Positive effects of negative publicity: When negative reviews increase sales. Marketing Science, 29(5), 815-827. doi: $10.1287 / \mathrm{mksc} .1090 .0557$

Bhattacharya, C. B. ve Sen, S. (2003). Consumer-company identification: A framework for understanding consumers' Relationships with companies. Journal of Marketing, 67(2), 76-88. doi: 10.1509/jmkg.67.2.76.18609

Brammer, S., Hongwei, H. ve Kamel, M. (2015). Corporate social responsibility, employee organizational identification, and creative effort: The moderating impact of corporate ability. Group and Organization Management, 40(3), 323-352. doi: 10.1177/1059601114562246

Brown, T. J. ve Dacin, P. A. (1997). The company and the product: Corporate associations and consumer product responses. The Journal of Marketing, 68-84. doi: $10.1177 / 002224299706100106$

Buckley, P. G. (1991). An SOR model of the purchase of an item in a store. ACR North American Advances, $\quad 18, \quad 491-500 . \quad$ Erişim adresi: https://www.acrwebsite.org/volumes/7138/volumes/v18/NA-18

Cheney, G. ve Tompkins, P. K. (1987). Coming to terms with organizational identification and commitment. Communication Studies, 38(1), 1-15. doi: 10.1080/10510978709368225

Choi, L.ve Huddleston, P. (2014). The effect of retailer private brands on consumer-based retailer equity: Comparison of named private brands and generic private brands. The International Review of Retail, Distribution and Consumer Research,24(1), 59-78. doi: 10.1080/09593969.2013.821417

Chung A. ve Jiang H. (2017). Handling negative publicity the influence of employing CSR communication in apology statements in reducing anger and negative word-of-mouth (NWOM). Journal of Communication Management, 21(3), 267-286. doi: 10.1108/JCOM-112016-0091

Cornwell, T. B. ve Coote, L. V. (2005). Corporate sponsorship of a cause: The role of identification in purchase intent. Journal of Business Research, 58(3), 268-276. doi: 10.1016/S0148-2963(03)00135-8 
Creyer, E. H. (1997). The influence of firm behavior on purchase intention: Do consumers really care about business ethics?. Journal of Consumer Marketing, 14(6), 421-432. doi: $10.1108 / 07363769710185999$

Dawar, N. ve Pillutla, M. M. (2000). Impact of product-harm crises on brand equity: The moderating role of consumer expectations. Journal of Marketing Research, 37(2), 215-226. doi: 10.1509/jmkr.37.2.215.18729

Dean D. H. (2004). Consumer reaction to negative publicity: Effects of corporate reputation, response, and responsibility for a crisis event. Journal of Business Communication, 41(2), 192211. doi: $10.1177 / 0021943603261748$

Deephouse, D. (2002). The term 'Reputation Management': Users, uses and the trademark tradeoff corporate reputation: An eight-country analysis. Corporate Reputation Review, 5(1), 9-18. doi: 10.1057/palgrave.crr.1540161

Devrani, T. ve Tüzün, İ. (2008). Müşteri vatandaşlık davranışının öncüllerinin belirlenmesine yönelik bir araştırma. İstanbul Ticaret Üniversitesi Sosyal Bilimler Dergisi, 7, 193-208. Erişim adresi:

http://88.255.149.215/xmlui/bitstream/handle/11467/383/M00213.pdf?sequence=1\&isAllow ed $=\mathrm{y}$

Dodds, W. B., Monroe, K. B. ve Grewal, D. (1991). Effects of price, brand, and store information on buyers' product evaluations. Journal of Marketing Research, 307-319. doi: $0.1177 / 002224379102800305$

Durmuş, B., Yurtkoru, E.S., ve Çinko, M. (2011). Sosyal bilimlerde SPSS 'le veri analizi. İstanbul: Beta Yayıncilik.

Dutton, J., Dukerich J. ve Harquail, C.V. (1994). Organizational images and membership commitment. Administrative Science Quarterly, 34, 191-206. Erişim adresi: http://eds.b.ebscohost.com/eds/pdfviewer/pdfviewer?vid=0\&sid=181b738f-f05a-430f-936e$15375066 f 4 c 4 \% 40$ pdc-v-sessmgr05

East, R., Hammond, K. ve Lomax, W. (2008). Measuring the impact of positive and negative word of mouth on brand purchase probability. International Journal of Research in Marketing, 25(3), 215-224. doi: 10.1016/j.ijresmar.2008.04.001

Edwards, M. R. ve Peccei, R. (2007). Organizational identification: Development and testing Of A conceptually grounded measure. European Journal of Work and Organizational Psychology, 16(1), 25-57. doi: 10.1080/13594320601088195

Feldman, P.M., ve Vasquez-Parraga, A.Z. (2013). Consumer social responses to CSR initiatives versus corporate abilities. Journal of Consumer Marketing, 30(2), 100-111. doi: $10.1108 / 07363761311304915$

Fishbein, M. ve Ajzen, I. (1975). Belief, attitude, Intention, and behavior: An introduction to theory and research. Reading, MA: Addison-Wesley.

Fombrun, C. J., Van Riel, C. B: M. ve Van Riel, C. (2004). Fame \& fortune: how successful companies build winning reputations. New Jersey: FT Press.

Hair, J. F., Black, W. C., Babin, B. J. ve Anderson, R. E. (2014). Multivariate data analysis: international edition. Harlow: Pearson Educaiton.

Hall, D. T., Schneider, B. ve Nygren, H. T. (1970). Personal factors in organizational identification. Administrative Science Quarterly, 176-190. doi: 10.2307/2391488

Ham, C-D., Cho, C-H. ve Woo, J. (2012). Positive vs. negative publicity with advertising an application of the Synergy on country brand and country-of-origin products. International Journal of Integrated Marketing Communications, Fall, 27-43. Erişim adresi : 
http://eds.a.ebscohost.com/eds/pdfviewer/pdfviewer?vid=0\&sid=3b0b5e5a-9cb6-4172-99457f7b1b6101ea\%40sdc-v-sessmgr03

Hayes, A. F. (2013). Introduction to mediation, moderation, and conditional process analysis. New York: Guilford Publications.

Herbig, P. ve Milewicz, J. (1993). The relationship of reputation and credibility to brand success. Journal of Consumer Marketing, 10(3), 18-24. doi: 10.1108/EUM0000000002601

Hoye, G. V. ve Lievens F. (2005). Recruitment-related information sources and organizational attractiveness: Can something be done about negative publicity?. International Journal of Selection and Assessment, 13(3), 179-187. doi: 10.1111/j.1468-2389.2005.00313.x

Gendel-Guterman H. ve Levy, S. (2017). Consumer response to private label brands'negative publicity: A relational effect on retailer's store image. Journal of Product \& Brand Management, 26(2), 204-222. doi: 10.1108/JPBM-05-2015-0880

Grewal, D., Monroe, K. B. ve Krishnan, R. (1998). The effects of price-comparison advertising on Buyers' perceptions of acquisition value, transaction value, and behavioral intentions. The Journal of Marketing, 46-59. doi: 10.1177/002224299806200204

Griffin, M., Babin, B.J. ve Attaway, J.S. (1991). An empirical investigation of the impact of negative public publicity on consumer attitudes and intentions. Advances in Consumer Research, 18, 334-341. Erişim adresi: https://www.acrwebsite.org/volumes/7182/volumes/v18/NA-18

Grubb, E. L. ve Hupp, G. (1968). Perception of self, generalized stereotypes, and brand selection. Journal of Marketing Research, 58-63. doi: 10.1177/002224376800500107

Gürhan-Canli, Z., ve Batra, R. (2004). When corporate image affects product evaluations: The moderating role of perceived risk. Journal of Marketing Research, 41(2),197-205. doi: 10.1509/jmkr.41.2.197.28667

Kalwani, M. U. ve Silk, A. J. (1982). On the reliability and predictive validity of purchase intention measures. Marketing Science, 1(3), 243-286. doi: 10.1287/mksc.1.3.243

Keh, H.T. ve Xie, Y. (2009). Corporate reputation and customer behavioral intentions: The roles of Trust, identification and commitment. Industrial Marketing Management, 98, 732-742. doi: 10.1016/j.indmarman.2008.02.005

Kim, S., (2013). What's worse in times of product-harm crisis? Negative corporate ability or negative CSR reputation?. Journal of Business Ethics, 123, 157-170. doi: 10.1007/s10551-013$1808-x$

Kim, S., Kim, S.-Y. ve Sung, K.H. (2014). Fortune 100 Companies' Facebook strategies: corporate ability versus social responsibility. Journal of Communication Management, 18(4), 343-362. Erişim adres: https://www.emerald.com/insight/content/doi/10.1108/JCOM-012012-0006/full/html

Labay, Duncan G. ve Kinnear, T.C. (1981). Exploring the consumer decision process in the adoption of solar energy systems. Journal of Consumer Research, 8(3), 271-278. doi: $10.1086 / 208865$

Lii, Y. ve Lee, M. (2012). Doing right leads to doing well: When the type of CSR and reputation interact to affect consumer evaluations of the firm. Journal of Business Ethics, 105, 69- 81. doi: 10.1007/s10551-011-0948-0

Lin, C.P., Chen, S.C., Chiu, C.K. ve Lee, W. Y. (2001). Understanding purchase intention during product-harm crises: Moderating effects of perceived corporate ability and corporate social responsibility. Journal of Business Ethic, 102, 455-471. doi: 10.1007/s10551-011-0824-y 
Liu X., Lischka, H.M. ve Kenning P. (2018). Asymmetric cognitive, emotional and behavioural effects of values-related and performance-related negative brand publicity. Journal of Product \& Brand Management, 27(2), 128-145

Luo, X. ve Bhattacharya, C. B. Corporate social responsibility, customer satisfaction, and market Value. Journal of Marketing, 70(4), 1-18. doi: 10.1509/jmkg.70.4.001

Mael, F., \& Ashforth, B. E. (1992). Alumni and their Alma Mater: A partial test of the reformulated model of organizational identification. Journal of Organizational Behavior, 13(2), 103-123. doi: 10.1002/job.4030130202

Marquina, P. ve Morales, C. E. (2012). The influence of CSR on purchasing behaviour in Peru and Spain. International Marketing Review, 29(3), 299-312. doi: $10.1108 / 02651331211229778$

Menon, G, Jewell, R. D. ve Unnava, H.R. (1999). When a company does not respond to negative publicity:Cognitive elaboration vs. negative affect perspective. Advances in Consumer Research, 26, 325-329.

Pavlou P.A. (2003). Consumer acceptance of electronic commerce: Integrating trust and risk with the technology acceptance model. International Journal of Electronic Commerce, 7(3), 101134. doi: 10.1080/10864415.2003.11044275

Podsakoff, P.M., MacKenzie, S.B., Lee, J.Y. ve Podsakoff, N.P. (2003). Common method biases in behavioral research: A critical review of the literature and recommended remedies. Journal of Applied Psychology, 88(5), 879-903. doi: 10.1037/0021-9010.88.5.879

Pullig, C., Netemeyer, R.G. ve Biswas A. (2006). Attitude basis, certainty, and challenge alignment: A case of negative brand publicity. Journal of the Academy of Marketing Science, 34(4), 528-542. doi: 10.1177/0092070306287128

Sharma, S., Durand, R. M., ve Gur-Arie, O. (1981). Identification and analysis of moderator variables. Journal of Marketing Research, 18(3), 291-300. doi: $10.1177 / 002224378101800303$

Sohn, Y. J. ve Lariscy, R. W. (2015). A buffer or boomerang?-The role of corporate reputation in bad times. Communication Research, 42(2), 237-259. doi: 10.1177/0093650212466891

Sun, B. ve Morwitz, V. G. (2010). Stated intentions and purchase behavior: A Unified model. International Journal of Research in Marketing, 27(4), 356-366. doi: 10.1016/j.ijresmar.2010.06.001

Swart, H., Turner, R., Hewstone, M. ve Voci, A. (2011). Achieving forgiveness and trust in postconflict societies: the importance of self-disclosure and empathy, L. R. Tropp ve R. K. Mallett (Ed.), Moving beyond prejudice reduction: pathways to positive intergroup relation (s.181-200) içinde New York, NY: Oxford University Press.

Tajfel, H. (1978). Differentiation between Social groups. Study in social psychology of intergroup relation. London: Academic Press.

Tajfel, H. ve Turner J.C. (1985). The social identity theory of intergroup behavior. S.Worchel ve W.G. Austin (Ed), The Psychology of intergroup relations içinde (Vol 2). Chicago: Nelson Hall.

Tsai, Y.-H., Lin, C.-P., Ma, H.-C., ve Wang, R.-T. (2015). Modeling corporate social performance and Job Pursuit intention: Forecasting the job change of professionals in technology industry. Technological Forecasting and Social Change, 99, 14-21. doi: 10.1016/j.techfore.2015.06.026 
Turner, J. C. (1985). Social Categorization and The self-concept: A social-cognitive theory of group behavior. J.Lawler (Ed), Advances in group processes: Theory and research içinde (Vol. 2). Greenwich, CT: JAI Press.

Um, N-H. (2013). Effects of negative brand information: Measuring impact of celebrity identification and brand commitment. Journal of Global Marketing, 26, 68-79. doi: 10.1080/08911762.2013.804614

Van Knippenberg, D., Van Dick, R. ve Tavares, S. (2007). Social identity and social exchange: identification, support, and withdrawal from the job. Journal of Applied Social Psychology, 37(3), 457-477. doi: 10.1111/j.1559-1816.2007.00168.x

Vanhamme J. ve Grobben, B. (2009). Too Good to be True!. The effectiveness of CSR history in countering negative publicity. Journal of Business Ethics, 85(2), 273-283.

Walsh, G. ve Bartikowski, B. (2013). Exploring corporate ability and social responsibility associations as antecedents of customer satisfaction cross-culturally. Journal of Business Research, 66,989-995. doi: 10.1016/j.jbusres.2011.12.022

Wegge, J, Van Dick R, Fisher G. K., Wecking C. ve Moltzen K. (2006). Work motivation, organizational 1dentification, and well-being in Call Centre Work. Work \& Stress, 20(1), 6083. doi: 10.1080/02678370600655553

Weiwei, T. (2007). Impact of corporate 1mage and corporate reputation on customer loyalty: A review. Management Science and Engineering, 1(2), 57-62. doi: 10.3968/j.mse.1913035X20070102.008

Xie, Y. (2014). The Effects of corporate ability and corporate social responsibility on winning customer support: An integrative examination of the roles of satisfaction, trust and identification. Global Economic Review, 43(1), 73-92. doi: 0.1080/1226508X.2014.884050

Yoo, B. ve Donthu, N. (2001). Developing a scale to measure the perceived quality of an internet shopping site (SITEQUAL). Quarterly Journal of Electronic Commerce, 2(1), 31-45.

Zarei, A. ve Maleki, F. (2018). From decision to run: The moderating role of green skepticism. Journal of Food Products Marketing, 24(1), 96-116. doi: 10.1080/10454446.2017.1266548

Zhou, Y., Poon, P. ve Huang, G. (2012). Corporate ability and corporate social responsibility in a developing Country: The role of product involvement. Journal of Global Marketing, 25,4556. doi: 10.1080/08911762.2012.697385

Zhu, D. H. ve Chang, Y.P. (2013). Negative Publicity effect of the business Founder's Unethical behavior on corporate image: Evidence from China, Journal of Business Ethics, 117(1), 111121. doi: 10.1007/s10551-012-1512-2

\section{ETİK ve BİLIMSEL İLKELER SORUMLULUK BEYANI}

$\mathrm{Bu}$ çalışmanın tüm hazırlanma süreçlerinde etik kurallara ve bilimsel atıf gösterme ilkelerine riayet edildiğini yazar(lar) beyan eder. Aksi bir durumun tespiti halinde Afyon Kocatepe Üniversitesi Sosyal Bilimler Dergisi'nin hiçbir sorumluluğu olmayıp, tüm sorumluluk makale yazarlarına aittir. 